\title{
Enabling Idea Generation through Computer-Assisted Collaborative Learning
}

\author{
Andrei Niculescu ${ }^{1}$, Gisli Thorsteinsson ${ }^{2}$ \\ 1 Spiru Haret University, \\ 13, Ion Ghica Street, Bucharest 3, Romania. \\ andreiniculescu@hotmail.com \\ 2 University of Iceland, \\ v/Stakkahlid, 101, Reykjavik, Iceland. \\ cdt@hi.is
}

\begin{abstract}
This article puts forward a three related case study series, using a Virtual Reality Learning Environment (VRLE) with a view to supporting the development of students' ideation skills in conventional primary and secondary education. Since this learning environment is fairly new it is necessary to examine its educational uses and determine if the new learning environment will meet teachers' expectations. Therefore, the overall goal for this research was twofold: a) to explore the ways in which idea generation was developed during students' work in an enjoyable environment b) to assess the way VRLE affects students' ability to generate new ideas and pass on knowledge. The data collected was qualitative and the analysis was based on grounded theory principles and an interpretive paradigm.

Keywords: Idea generation, collaborative learning, computer-assisted learning, Virtual Reality Learning Environment, pedagogy, ideation process.
\end{abstract}

\section{Introduction}

Computer-Assisted Collaborative Learning (CACL) is commonly described as a situation in which two or more people learn or work together, usually aiming for dissimilar goals (Dillenbourg, 1999; Chiu, 2000). Students involved in Computer-Assisted Collaborative Learning benefit from one another's resources and skills. This can include assessing each other's ideas, asking one another for information and observing each other's work (Chiu, 2000). CACL can, furthermore, be described as computer-based network systems that upkeep group work for a joint purpose and provide a shared interface for a team to work with (Ellis et al., 1991; Stahl et al., 2006).

In CACL, computers are used within an educational setting to facilitate and support collaborative group learning processes. The main purpose is to support students in learning together effectively, for example, communicating ideas, accessing information and providing feedback on problem-solving activities (Stahl et al., 2006).

The paper reports three case study series which took place in several elementary and secondary school classes (six to sixteen-year-old students; various groups of volunteers, from the seventh class onwards, took part in the research). The background of the VRLE is described and the overall aims, objectives and research questions stated. Idea generation is defined and a specific model for idea generation demonstrated. The research methods are explained and findings reported. Subsequently these findings are discussed and conclusions drawn.

\section{Related Approaches to Idea Generation}

The term Ideation originated from Guilford (1950), Thompson (2008) that used it to describe the pattern of interactions that arise when an individual produces an idea. As The Oxford Dictionaries Online (2011) states, ideation is the formation of ideas or mental images of things not present to the senses. Idea generation is the generation of possibilities, performed at various points in problem solving and innovation episodes (Smith, 2003). Lying at the heart of both invention and design, it is widely acknowledged as a key part of the innovation process (Van de Ven et al., 2000).

Innovation is closely related to idea generation, as the innovation process invariably includes problem-need identification and problem solving (Smith, 2003). Osborn (1967) understood idea generation and idea evaluation as a two separate activities. Demerest (1997), similarly, recognised knowledge creation as a key separate activity supportive of idea generation. Rickards and Freedman (1978) suggest that an additional time separation or deferment of judgement should occur in the idea generation phase, as this time factor allows ideation to develop before idea evaluation takes 
place. Titus (2000) speaks of periods of idea generation rather than separated events, suggesting the need for reflection and further development. Similarly, Henry (1991) considers the need for a period of incubation in idea generation: this period is referred to as deferred judgement and is distinct from dormancy. Rather, it should be a period of knowledge creation through dialogue, debates, scanning, etc. Accordingly, ideas are generated and shaped, prior to idea evaluation.

Modern technology can be used to support collaborative ideation. Computer technologies and the Internet are now an everyday part of students' lives and are arguably becoming the preferred mode of both communication and the collection of information (Hennessey \& Deaney, 2004; Passey et al., 2004). As the use of the VRLE was new and the learning and teaching context complex and dynamic, the focus became the exploration of the use of the VRLE to support student ideation work (Thorsteinsson, Page and Niculescu, 2010a). The intention was to identify the issues involved, to use literature and fieldwork to understand how these issues were related and, eventually, to be able to prepare a map of directions for further research. was an online $V R L E$, linked to a database: this $V R L E$ was developed as a combination of the managed learning environment $(M L E)$ and the virtual reality environment (VRE). The MLE provided the framework for teachers to manage student learning, while the VRE provided a simple virtual environment that enabled students to meet and communicate through a number of means, such as voice, text, drawings, photographs and presentations. The database enabled these ideas to be shared and recorded and these, as a whole, represented the VRLE.

The VRLE is potentially a tool for experiential learning, as it provides various dynamic and rapid ways to see, experience and generate ideas and information. The VRLE can be used as a tool for problem solving and communicating ideas and includes the possibility of promoting a high degree of interactivity and immersion (Ogle, 2002; Bricken, 1991; Johnson et al., 2002; Jonassen, 2006; McLellan, 1996; Osberg, 1993). The VRLE is interactive in two ways: firstly, a user interacts with data in the database within the VRLE and also beyond; for example, via the World Wide Web (www). Secondly, it allows the interaction of a number of students and staff within the VRLE, using a range of modes including speech, drawing and writing.

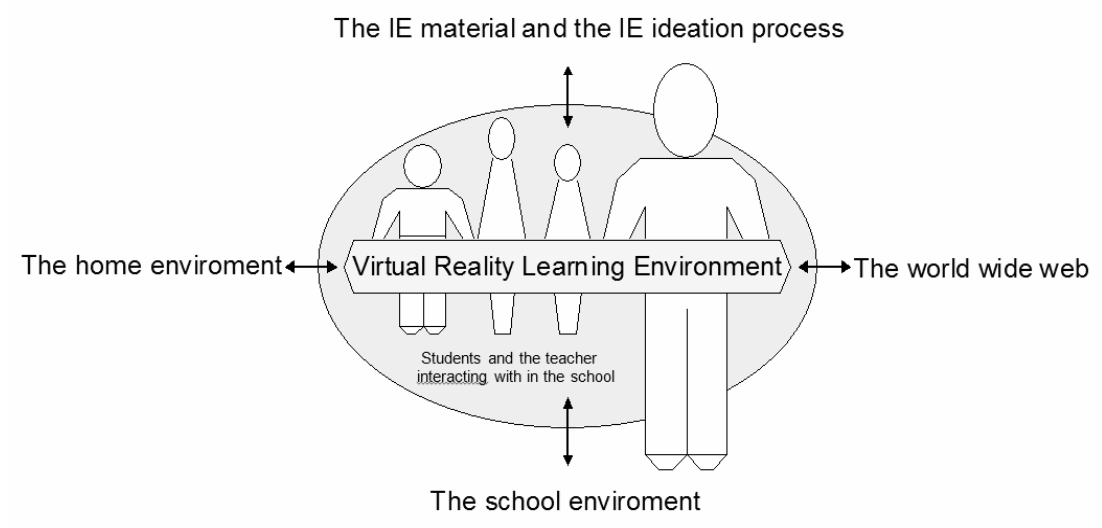

Figure 1. The VRLE offers different dimensions of communication

\section{Using a VRLE to Support Idea Generation}

The original idea behind the VRLE was to find a new way of supporting students' ideation work, using information and computer technology (Thorsteinsson and Denton 2003). The specific VRLE was designed to enhance ideation via collaborative learning support and thus creating individual and social educational opportunities. The main output of the project
Students could be from the same class or in other schools or countries, accessing the VRLE via the www. Using the VRLE within the classroom context offers multi-modal communication and this would be expected to influence students' learning experiences.

The main reasons for students using the VRLE were to:

- offer another enjoyable mode of working together, in terms of ideas, sharing 
problems, solving such problems and developing solutions;

- enable students to meet each other and their teacher online;

- facilitate easy communication inside virtual 3D spaces, where students and teachers could meet in real time, share information and work together with ideas;

- provide the opportunity to develop certain skills within the ideation process (i.e., brainstorming, drawing and discussion).

\section{A Pedagogical Model for Idea Generation}

The research activities were built on the following model for Idea generation (Thorsteinsson \& Denton, 2003 (see figure 2). They were based on a series of steps, iterations and relationships, with the overlying direction leading from 'finding needs' to 'presentation of solutions'.

1. Finding needs;

2. Brainstorming;

3. Creating and choosing initial solutions;

4. Concept drawing or modelling, in order to develop the technical solution;

5. Creating a description of the solution, in addition to the drawing;

6. Presentation.
Ideation skills are employed at all stages of the innovation process and innovation relates to the usefulness of ideas and/or how they can be implemented as solutions to many problems encountered in everyday life. Students learn through the cycles of the innovation process, supported by the collaboration amongst individuals, as a group, and by the teacher. The overall framework is managed by the teacher (see Figure 2).

A course plan and related research plan were established, on the aim and research questions. The teacher set up email accounts and registered them to the VRLE; he also took digital photographs, in order to enable the students to personalise their VRLE workshops. The classroom used was an ordinary classroom, with 12 network connected computers and digital drawing output devices. For computer-based VRLE activities, 8 students were adequate. While this was a small sample, it did enable a close focus on the group and was consistent with enabling pedagogical issues to emerge.

The various collaborative learning tasks designed for idea generation benefit from this virtual learning tool which enables students to connect to each other and the outside world, thus facilitating communication and knowledge transfer. While the VRLE has the potential to enable open and distance learning, in terms of co-operation between students and teachers

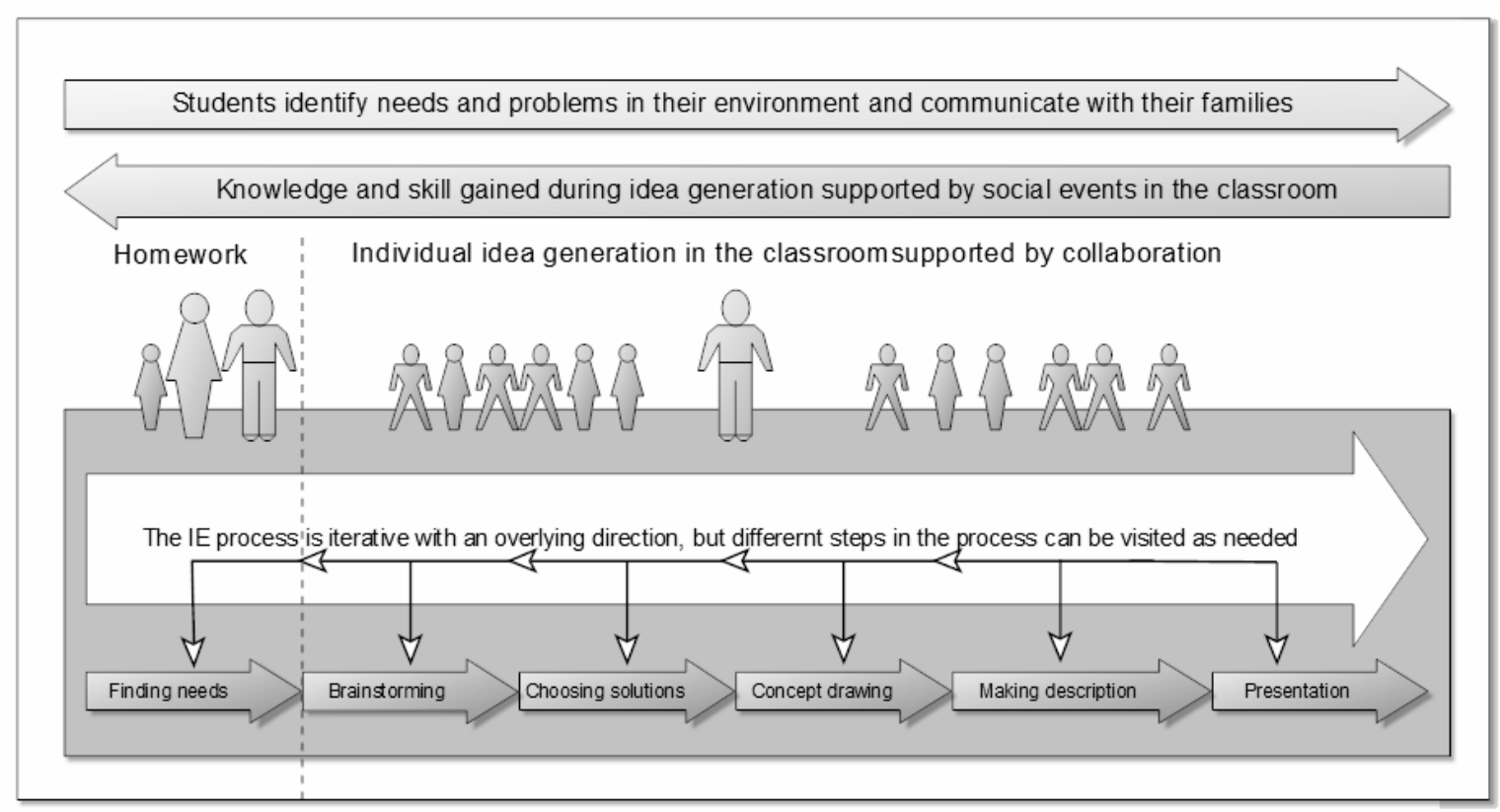

Figure 2. A basic pedagogical model for idea generation that illustrates innovation as a 'process', with appropriate feedback loops and options. 
across continents, it was decided that this would be too large a dimension for this research. Thus, the focus was limited to the use of the VRLE within the conventional classroom context.

\section{Research Methodology Development}

As the research took place in a complex social/educational context, grounded theory (Glaser and Strauss, 1967) principles were used as a way of observing, describing and interpreting settings as sources of data (grounded theory is a principle based on the systematic building of theory, using qualitative or/and quantitative data). The key points in the data are marked with a series of codes, which are then grouped into emerging conceptual categories. These categories are related to each other as a theoretical explanation of the action(s) that continually resolve the main concerns of the participants within a substantive area (Denzin, 1984).

Grounded theory focuses on obtaining an abstract analytical schema of a phenomenon that relates to a particular situation (Creswell, 1998). However, Strauss \& Corbin (1998) explicitly pointed out that the value of grounded theory lies in its ability not only to generate the theory, but also to ground that theory in data. This inductive method is particularly helpful in identifying patterns of behaviour or thought in a particular group of people, as in this study.

Further reading on the principles of grounded theory and specific research methods appropriate to this educational context (Glaser \& Strauss, 1967; Cohen et al., 2005) led to the design of a programme of case studies intended to explore the research questions. Three case studies were undertaken, each based on a programme of lessons, and these were used iteratively, in that a period of analysis and reflection followed each case study and led into the next. An action research phase was used to further develop the pedagogical model. Issues were identified and tested in terms of the use of the VRLE in classroom environments.

Specific techniques were used for data collection including interviewing, observations and document analysis. The use of different data sources helped the researcher to 'validate and crosscheck findings' (Patton, 1990:244). In the case study series, different types of qualitative data were collected in the form of interviews with the participating teacher and students; classroom observations; video recordings of students' activity when using the VRLE; screen video recordings; student work samples and the teacher's and researcher's logbooks. These multiple perspectives offered a good degree of triangulation (Denzin, 1984; Cohen et al., 2005).

\section{General Findings}

Throughout the research the VRLE worked well in general; it was stable and easy to register the students. However, dealing with the VRLE technology might have been more difficult for a teacher without strong information technology skills. Probably due to good computer literacy, students learned to use the VRLE through direct experience. Using the VRLE network inside the classroom made it possible for students to learn from one another both face-to-face and online. They also got some instruction from the teacher. They quickly became self-reliant but the teacher considered they needed more concrete learning material and a traditional instructional phase.

The teacher's role was to help students to understand the innovation process. Training them via the VRLE was beneficial for their idea generation. Normally, students quickly understood the innovation process and were able to identify needs and problems in their own environment. Identifying problems and needs at home played a significant role in the first stages of the innovation process that took place at home. This was intended to trigger idea generation in lessons, helping students to generate the content of the course, make them self-directed and give a personal value and meaning to their work.

Students usually defined their findings spontaneously and tended to record solutions in their notebook, instead of needs and problems. However, the teacher was able to help them to define needs rather than solutions by means of discussions held while they worked inside the VRLE without imposing his own value judgements.

The VRLE directed students' idea generation as it was structured upon the idea generation process. The VRLE facility for sharing needs, solutions and brainstorming during classroom activities was identified as beneficial. Students 
frequently shared needs and problems with each other, both face-to-face and online. There was a balance between needs identified at home and at school. However, most ideas were generated when students were working collaboratively inside the VRLE. Students worked individually but supported each other by sharing their knowledge via the VRLE. The students generated similar amounts of needs and solutions and there was a balance between boys (20) and girls (20). Just one in the group shared their needs with one or more individuals and two shared their needs with the group. Four students shared nine solutions with individual students and with the whole group. Forty solutions were delivered in total and 35 needs. The students established two group needs and sixteen group solutions. Most often, there was a congruency between the students' needs and solutions.

\section{Discussion and Conclusions}

The VRLE guided the students work, gave structure and reflected the role of the computer as a tutor, tutee and tool (Blom and Monk, 2003; Taylor, 1980) and enabled both CSCL and CSCW (Thorsteinsson and Denton, 2008 and Thorsteinsson, Page and Niculescu, 2010b). The VRLE worked as a tool students used to enable their work. It included help pages and was structured on the innovation process. This structure and help pages guided and directed students during their work and was therefore a form of tutee.

During the research, students had no major problems in using the VRLE and quickly became self-reliant (Thorsteinsson and Denton, 2008). Their confidence and IT ability enabled them to start using the VRLE easily. However, the case studies showed that additional training was needed to comply with the hardware requirements (specifically the graphical input devices) and the VRLE. The teacher also considered students needed training in using the VRLE for cooperative idea generation (Thorsteinsson, Page and Niculescu, 2010a).

Social presence was an important aspect of using the VRLE and enabled a community of learners to grow as Hamburg et al. (2003) Hauber et al. (2005) have indicated. Playing informally in the VRLE was shown to promote the students' skills and confidence in using the VRLE, and familiarity with each other
(Prensky, 2005; Hussain et al., 2003). The case studies indicated that being physically together and being able to speak to the teacher both inside the classroom and over the Internet at the same time appeared to assist students learning, probably via having multiple modes of communication (see also Loiselle et al., 1998 \& Schrum \& Berenfeld, 1997; Thurlow, Lengel, \& Tomic, 2004; Romiszowski \& Mason, 1996). The capability of students personalising the interface of their virtual workshops appeared to be important in relation to increasing their perception of relevance and ownership of the VRLE, echoing Oulasvirta and Blom, (2008) and Blom and Monk, (2003).

It was the teacher's role to help students to understand the innovation process (Gunnarsdottir, 2001) both with and without the VRLE (Thorsteinsson and Denton, 2008). They quickly became familiar with the innovation process in so far as they can bring basic ideas to school to act as start points for effective collaborative idea development. However, it was evident that students in the case studies did not understand the fine differences between problems, opportunities, needs and initial ideas. This may be due to their relative immaturity (age $11-12$ ) but is certainly an area that merits further specific research.

Collaboration played an important role, both at home, in the classroom and inside the VRLE to facilitate idea generation, supporting the position of Hamburg et al. (2003). Training students in idea generation via the VRLE and in the classroom appeared to be encouraging selfreliance and independence and appeared to be beneficial for idea generation. It furthermore gave the teacher a little more freedom to stand back and observer the group carefully. This supported him in adopting the role of a facilitator to a greater extent (Thorsteinsson and Denton, 2008).

The VRLE was structured upon the innovation process and included a facility to brainstorm and share needs and solutions. It can be seen as an interactive, collaborative, learning tool supporting idea generation. Students often shared needs and solutions inside the VRLE (Thorsteinsson, Page and Niculescu, 2010a).

Students in the case studies were generally selfreliant and worked most often individually inside the $M L E$ part of the VRLE, but also collaboratively inside the $V R E$ at the same 
time. This collaboration was supportive for individually based idea generation (Dennis \& Valacich, 1993). However, students were still less productive and fewer ideas were generated as it was time consuming (as with Taylor et al., 1958 and Paulus et al., 1995). Being able to play inside the VRE, when working in the MLE, was a form of informal "edutainment" that supported collaboration and skill (O'Quin and Derks, 1999). A light-hearted spirit in lessons appeared to positively influence idea generation, supporting the position of O'Quin and Derks (1999).

\section{REFERENCES}

1. BLOM, J. O., A. F. MONK, A Theory of Personalisation of Appearance: Why Users Personalise Their PCs and Mobile Phones, Human-Computer Interaction, Vol. 18, No. 3, 2003, pp. 193-228.

2. BRICKEN, M., Virtual Reality Learning Environments: Potentials and Challenges, Computer Graphics, Vol. 25, No. 3, 1991, pp. 178-184.

3. CHIU, M. M. Group Problem Solving Processes: Social Interactions and Individual Actions, Journal for the Theory of Social Behaviour, Vol. 30, No. 1, 2000, pp. 27-50.

4. COHEN, L., L. MANION, K. MORRISON, Research Methods in Education (5th ed.), Taylor \& Francis eLibrary, London, 2005.

5. CRESWELL, J. W., Qualitative Inquiry and Research Design: Choosing Among Five Traditions, Thousand Oaks, CA: Sage, 1998.

6. DEMEREST, M., Understanding Knowledge Management, Journal of Long Range Planning, Vol. 30, No. 3, 1997, pp. 374-384.

7. DENZIN, N. K., The Research Act, Englewood Cliffs, NJ. Prentice Hall, 1984.

8. DENZIN, N. K. Y. S. LINCOLN, (Eds), Handbook of Qualitative Research, Thousand Oaks, CA: Sage Publications, Inc, 1994.

9. DILLENBOURG, P., Collaborative Learning: Cognitive and Computational Approaches, Advances in Learning and
Instruction Series, New York, NY: Elsevier Science, Inc. 1999.

10. ELLIS, C. A., S. J. GIBBS, G. L. REIN, Groupware: Some Issues and Experiences, Communications of the ACM, Vol. 34, No. 1, 1991, pp. 38-58.

11. GLASER, B. G., A. L. STRAUSS, The Discovery of Grounded Theory: Strategies for Qualitative Research, New York, Aldine Publishing Company, 1967.

12. GUILFORD, J. P., Creativity, American Psychologist, Vol. 5, No. 9, 1950, pp. 444-454.

13. GUNNARSDOTTIR, R., Innovation Education: Defining the Phenomenon, Unpublished doctoral thesis, Leeds, University of Leeds, 2001.

14. HAMBURG, I., C. LINDECKE, H. T. THIJ, Social Aspects of e-Learning and Blending Learning Methods, in Proceedings of the 4th European conference E-comm-line, Bucharest, 2003.

15. HAUBER, J., H. REGENBRECHT, A. HILLS, A. COCKBURN, M. BILLINGHURST, Social Presence in Two- and Three-dimensional Videoconferencing, Proceedings Presence Workshop, London 2005.

16. HENNESSEY, S., R. DEANEY, Sustainability and Evolution of ICT Supported Classroom Practice, 2004. Retrieved (5 April 2009) from http://131.111.153.52/istl/SAE041.doc.

17. HENRY, J. Creative Management, London, Sage Publications, 1991.

18. HUSSAIN, H., Z. C. EMBI, S. HASHIM, A Conceptualized Framework for Edutainment, Informing Science: InSite Where Parallels Intersect, 2003, pp. 1077-1083.

19. JOHNSON, A., T. MOHER, Y. CHOO, Y. J. LIN, J. KIM, Augmenting Elementary School Education with VR.IEEE Computer Graphics and Applications, March/April, 2002, pp. 6-9.

20. JONASSEN, D., A Constructivist's Perspective on Functional Contextualism, Educational Technology Research \& Development, Vol. 54, No. 1, 2006, pp. 43-47. 
21. LOISELLE, J., M. ST. LOUIS, L. DUPUY-WALKER, Giving Professional Help to Pre-service Teachers through Computer-mediated Communication, Paper presented at the Annual Meeting of the Association of Teacher Educators, Dallas, 1998.

22. MCLELLAN, H. Virtual Reality, in Jonassen D. (Ed.), Handbook of research for educational communications and technology, MA, Kluwer-Nijhoff Publishing. 1996, pp. 457-487.

23. O'QUIN, K., P. DERKS, Humour and Creativity: A Review of the Empirical Literature, in Runco, M. (Editor), Creativity research handbook, Vol. 1, Cresskill, NJ: Hampton Press, 1999, pp. 223-252.

24. OGLE, T., The Effects of Virtual Environments on Recall in Participants of Differing Levels of Field Dependence, PhD Dissertation, Virginia Polytechnic and State University, Blacksburg, VA, 2002.

25. OSBERG, K. M., Virtual Reality and Education: A Look at Both Sides of the Sword, 1993.

26. OSBORN, A. F., Applied Imagination: Principles and Procedures of Creative Problem Solving (Third Revised Edition), NY, Charles Scribner's Sons, 1967.

27. OULASVIRTA, A. J. BLOM, Motivations in Personalisation Behaviour, Interacting with Computers, Vol. 20, No.1, 2008, pp.1-16.

28. PASSEY, D., C. ROGERS, J. MACHELL, G. MCHUGH, The Motivational Effect of ICT on Pupils, Department of Educational Research Lancaster University, 2004.

29. PATTON, M. Q. Qualitative Evaluation and Research Methods (2nd ed.), Newbury Park, CA, Sage, 1990.

30. PAULUS, P. B., T. S. LAREY, A. H. ORTEGA, Performance and Perceptions of Brainstormers in an Organizational Setting, Basic and Applied Social Psychology, Vol. 17, No. 1-2, 1995, pp. 249-265.

31. PRENSKY, M., Engage Me or Enrage Me: What Today's Learners Demand, Educause Review, Vol. 40, 2005, pp. 6065. Retrieved (12. August, 2009) from http://www.hitl.washington.edu/publication $\mathrm{s} / \mathrm{r}-93-7 /$

32. RICKARDS, T., B. FREEDMAN, Procedures for Management in Ideadeficient Situations: An Examination of Brainstorming Approaches, The Journal of Management Studies, Vol. 15, No. 1, 1978, pp. 43-55.

33. ROMISZOWSKI, A. J., R. MASON, Computer-mediated Communication, in D. H. Jonassen (Ed.), Handbook of research for educational communications and technology, Simon \& Schuster Macmillan, New York, 1996, pp. 438-456.

34. SCHRUM, L., B. BERENFELD, Teaching and Learning in the Information Age: A Guide to Educational Telecommunications, Needham Heights: Allyn \& Bacon, 1997.

35. SMITH, G. F., Towards a Logic of Innovation, The International Handbook on Innovation, Elsevier Science Ltd., 2003.

36. STAHL, G., T. KOSCHMANN, D. SUTHERS, Computer-supported Collaborative Learning: An Historical Perspective, in R. K. Sawyer (Ed.), Cambridge handbook of the learning sciences, Cambridge University Press, Cambridge, UK, 2006, pp. 409-426.

37. STRAUSS, A. J. CORBIN, Basics of Qualitative Research: Techniques and Procedures for Developing Grounded Theory, Thousand Oaks, Sage Publications, CA, 1998.

38. TAYLOR, D. W., P. C. BERRY, C. H. BLOCK, Does Group Participation When Using Brainstorming Facilitate or Inhibit Creative Thinking?, Administrative Science Quarterly, Vol. 3, No. 1, 1958, pp. 23-47.

39. TAYLOR, R., The Computer in the School: Tutor, Tool, Tutee, Teachers College Press, New York, 1980.

40. The Oxford Dictionaries Online, Retrieved (5 April, 2011) from http://oxforddictionaries.com.

41. THOMPSON, L., Making the Team: A Guide for Managers (3rd ed.), Upper Saddle River, Prentice Hall, NJ, 2008. 
42. THORSTEINSSON, G., T. PAGE, A. NICULESCU, Adoption of ICT in Supporting Ideation Skills in Conventional Classroom Settings', Studies in Informatics and Control, Vol. 19, No.3, 2010a, pp. 309-318, ISSN 1200-1766.

43. THORSTEINSSON, G., H. G. DENTON, The Development of Innovation Education in Iceland: A Pathway to Modern Pedagogy and Potential Value in the UK, The Journal of Design and Technology Education, Vol. 8, No. 3, 2003, pp. 172-179.

44. THORSTEINSSON, G., H. G. DENTON, Developing an Understanding of the Pedagogy of using a Virtual Reality Learning Environment (VRLE) to Support Innovation Education (IE) in Iceland: A Literature Survey, Design and Technology Education: An International Journal, Vol. 13, No. 2, 2008, pp. 15-26, ISSN 1360-1431.
45. THORSTEINSSON, G., T. PAGE, A. NICULESCU, Using Virtual Reality for Developing Design Communication, Studies in Information and Control, Vol. 19, No. 1, 2010b, pp. 93-106, ISSN 1220-1766.

46. THURLOW, C., L. LENGEL, A. TOMIC, Computer Mediated Communication: Social Interaction and the Internet, Sage, London, 2004.

47. TITUS, P., Marketing and the Creative Problem-solving Process, Journal of Marketing Education, Vol. 22, No. 3, 2000, pp. 225-35.

48. Van de VEN, A., V. ANGLE, M. S. POOLE, Research on the Management of Innovation, Oxford University Press, Oxford, 2000. 